\title{
Lesser Canna Leafroller, Geshna cannalis (Quaintance) (Insecta: Lepidoptera: Pyralidae) ${ }^{1}$
}

Heather J. McAuslane ${ }^{2}$

\section{Introduction}

The lesser canna leafroller, Geshna cannalis (Quaintance), can be a serious pest of ornamental canna, Canna spp., in Florida. It is one of two leaf-rolling lepidopteran species found infesting canna, the other one being the larger and more voracious larger canna leafroller, Calpodes ethlius (Stoll). Cannas may be infested with both species simultaneously.

\section{Distribution}

Very little is known about the distribution of $G$. cannalis but it appears to be distributed throughout the southeastern United States. It has been recorded as a pest of canna in Florida (Kimball 1965), Mississippi, and North Carolina (see North Carolina Pest News). Since G. cannalis is a specialized pest of canna, which originated in the American tropics, it is likely that this insect species is also present in the neotropics.

\section{Description and Life History}

Adult G. cannalis are nondescript, small, light-brown pyralid moths which may be found resting in the shade of a canna plant during the day. The female wing span averages $25 \mathrm{~mm}$ (Quaintance 1898). There are two brownish black lines across the fore- and hindwings, and a small angular white patch near the distal portion of the discal cell of the forewing. Females lay eggs in groups of six to 15 on the upper surface of a canna leaf (Quaintance 1898). Eggs are flat, clear whitish yellow in color, and average $0.9 \mathrm{~mm}$ in size.

The first instars hatch and feed as leaf miners, tunneling between the upper and lower epidermis and excreting much frass into the tunnel. This first larval instar measures $1.4 \mathrm{~mm}$ in length and has a yellowish, somewhat transparent body, and a yellow head. After larvae become too large for their leaf mines, they feed gregariously on the upper leaf surface. When larvae are approximately one week old, they initiate leaf rolling behavior. Five or six larvae may be found within a leaf roll, but usually only one or two coexist.

1. This document is EENY-133, one of a series of Featured Creatures from the Entomology and Nematology Department, Florida Cooperative Extension Service, Institute of Food and Agricultural Sciences, University of Florida. Published: May 2000. This document is also available on Featured Creatures Website at http://creatures.ifas.ufl.edu. Please visit the EDIS Website at http://edis.ifas.ufl.edu. Additional information on these organisms, including many color photographs, is available at the Entomology and Nematology Department website at http://entnemdept.ifas.ufl.edu/.

2. Heather J. McAuslane, Entomology and Nematology Department, Institute of Food and Agricultural Sciences, University of Florida, Gainesville, FL 32611.

The Institute of Food and Agricultural Sciences (IFAS) is an Equal Employment Opportunity - Affirmative Action Employer authorized to provide research, educational information and other services only to individuals and institutions that function without regard to race, creed, color, religion, age, disability, sex, sexual orientation, marital status, national origin, political opinions or affiliations. For information on obtaining other extension publications, contact your county Cooperative Extension Service office. Florida Cooperative Extension Service / Institute of Food and Agricultural Sciences / University of Florida / Larry R. Arrington, Interim Dean 


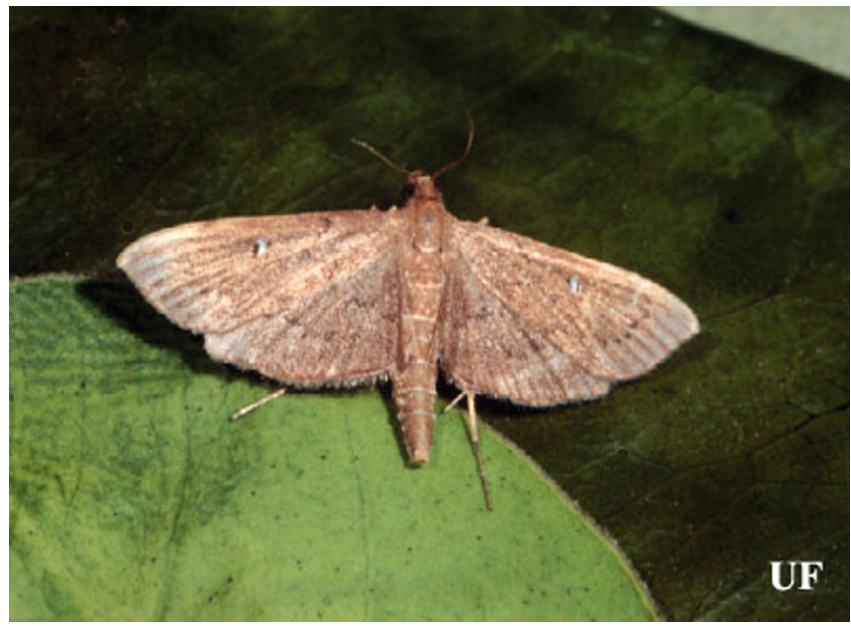

Figure 1. Adult of the lesser canna leafroller, Geshna cannalis (Quaintance). Credits: Paul M. Choate, University of Florida

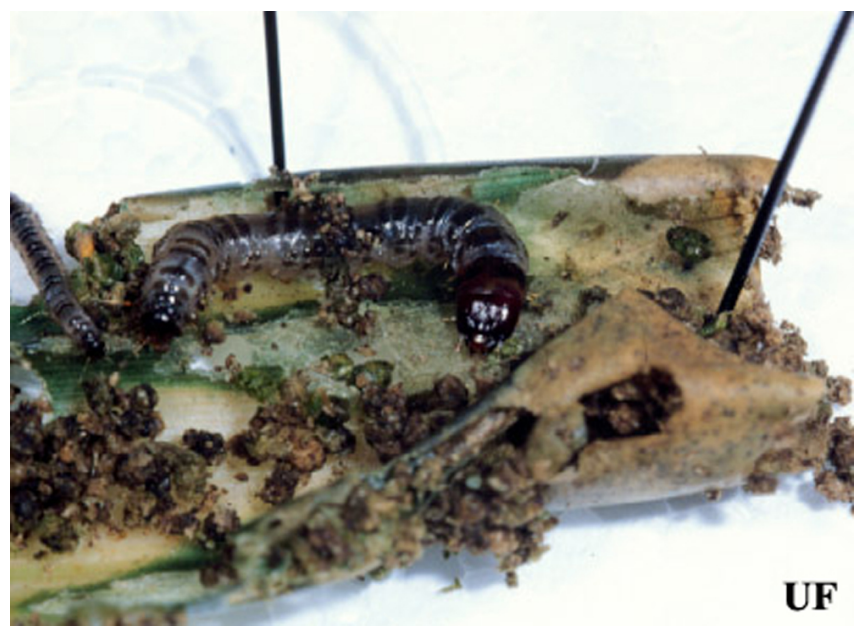

Figure 2. Rolled canna leaf showing feeding injury typical of the lesser canna leafroller, Geshna cannalis (Quaintance). Credits: Paul M. Choate, University of Florida

The last instar larva is about $23 \mathrm{~mm}$ in length and is yellowish white. Its body is transparent and the green color of its food is plainly visible through the integument. The head is yellow, with the clypeus yellowish brown and the tips of the mandibles brownish-black. The last instar larva spins a silken shelter within its leaf roll and pupates within the shelter. The pupa is $11.5 \mathrm{~mm}$ in length and is chocolate brown in color. There are eight stout dark brown hairs shaped into hooks on the caudal end of the pupa which hold the pupa in the silken shelter.

The pupal stage of the final generation of the year overwinters in dead canna leaves. Adult moths are usually first seen in late February and early March in Florida (Quaintance 1898). The first generation

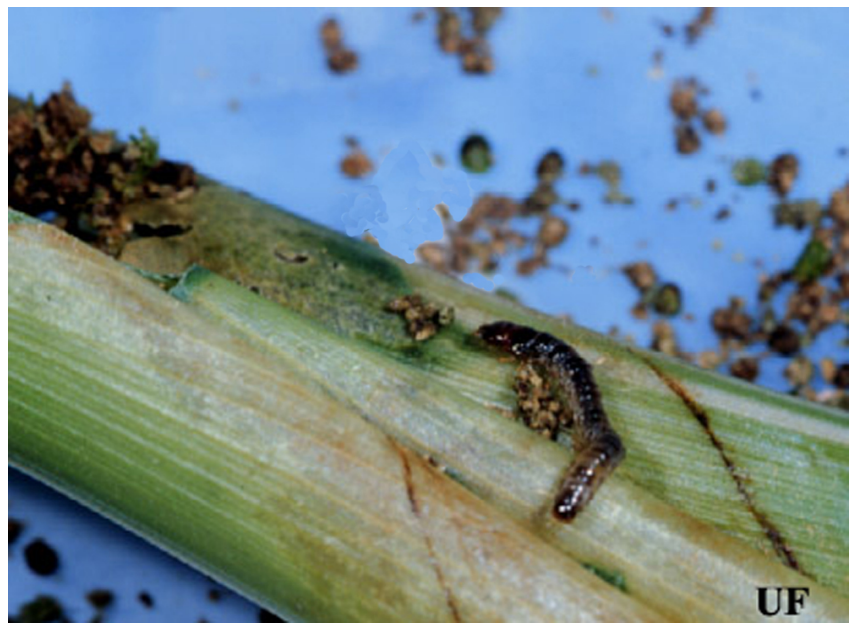

Figure 3. Late instar larva of the lesser canna leafroller, Geshna cannalis (Quaintance). Credits: Paul M. Choate, University of Florida

lasts 35 days while later generations during the summer are probably as short as 28 or 30 days. During the summer, the generations overlap and insects at all developmental stages can be found in the same canna planting.

\section{Hosts and Damage}

Geshna cannalis appears to be restricted to feeding on various species of canna. Its feeding damage can be readily distinguished from that of $C$. ethlius, the larger canna leafroller. Calpodes ethlius rolls up the edge of a fully expanded leaf and uses silk to hold the edges closed. Geshna cannalis may also feed this way, but it more frequently feeds within leaves that have not yet expanded (Quaintance 1898). It ties the unfurled leaf together with silk, preventing further expansion. Calpodes ethlius eats through the entire leaf surface whereas G. cannalis eats only the upper epidermis and parenchyma (the inner surface of the leaf roll), leaving the lower epidermis intact (Quaintance 1898). Finally, C. ethlius flicks away its frass so that the leaf roll is frass-free, whereas the feeding shelter of G. cannalis contains much dark brown frass.

\section{Management}

Cutting dead canna plants to the ground in the late winter is a good way to reduce populations of $G$. cannalis. Disposing of the cut material with the overwintering pupae will reduce initial population levels of this insect in the spring. During larval 


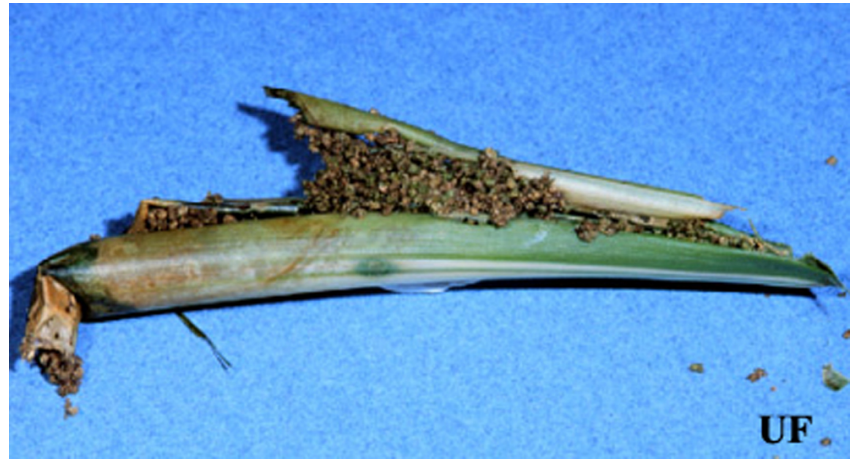

Figure 4. Frass-filled canna leaf roll containing larvae of the lesser canna leafroller, Geshna cannalis (Quaintance). Credits: Paul M. Choate, University of Florida

infestation in the summer, insecticides can be sprayed into the leaf roll, however, stickers must be added because the very waxy canna leaf surface repels water. Products that contain Bacillus thuringiensis (Bt) are least toxic to beneficial organisms. Other more toxic chemical alternatives are discussed in:

Insect Management on Landscape Plants http://edis.ifas.ufl.edu/IG013

Commercial Foliage and Woody Ornamental Arthropod Pest Management http://edis.ifas.ufl.edu/IG012

\section{Selected References}

Baker, J. R. Insect and related pests of flowers and foliage plants: some important, common, and potential pests in the southeastern United States. North Carolina State University. http://ipmwww.ncsu.edu/INSECT_ID/AG136/ ncstate.html (20 May 2000).

Kimball, C. P. 1965. The Lepidoptera of Florida: An annotated checklist. Division of Plant Industry, State of Florida Department of Agriculture, Gainesville, Florida.

Quaintance, A. L. 1898. Three injurious insects: bean leaf-roller, corn delphax, canna leaf-roller. Fla. Agric. Exp. Station Bull. 45: 53-74. 